\title{
Local Wisdom and Mitigation Action to Maintain Secondary Mangrove Forest: A Case Study of Jaring Halus Village in Langkat, North Sumatra, Indonesia
}

\author{
Mohammad Basyuni, Rahman A Rouf, Mahdi Saragih, Adnin M Asbi, Wahyunal Yuriswan
}

\author{
Department of Forestry, Faculty of Forestry \\ University of Sumatera Utara \\ Medan, Indonesia \\ m.basyuni@usu.ac.id
}

\begin{abstract}
Mangrove forest in the context of climate change belongs to the LULUCF (land use, land use change and forestry) sector is one of the important sectors to be included in the inventory of greenhouse gas (GHG) emissions. Mangrove forest plays an important role in the carbon cycle. The present study analyzes the perspective of local wisdom of Jaring Halus Village communities on the existence of mangrove forest and to describe the land-use and land-cover changes between 2006 and 2012 of Jaring Halus Village, Langkat, North Sumatra, Indonesia and their implications to carbon dioxide emissions. The results showed that community knowledge on the general role of mangrove and coastal protection was $85.5 \%$ and $71.4 \%$, respectively. Furthermore, $92.8 \%$ of the perspective of community was depicted that mangrove forests were greatly impacted to their lives, indicated that local wisdom contributed to maintaining the existence of mangrove forest in the village. A land-use change matrix demonstrated that there was very small increase from 2006 to 2012 in the land-use of secondary mangrove forest $(0.0033$ ha). The net cumulative of carbon emissions in Jaring Halus Village during 2006-2012 was -5.58 t $\mathrm{CO}_{2}$ eq/year, whereas predicting future emissions in 2016 was -16.74 t $\mathrm{CO}_{2}$-eq/year, suggesting carbon sequestration occurred in the mangrove forest. Mitigation actions were performed to increase carbon sequestration such as establishing nursery and planted after 3-6 months germinated, rehabilitation of degraded area, and unwritten rules concerning with the utility and cutting of mangrove trees with approval of village authority.
\end{abstract}

Keywords: Carbon dioxide emission; Jaring Halus Villages; land-use and land-cover change; local wisdom; mangrove forest

\section{INTRODUCTION}

Indonesia has $22.6 \%$ of the world's mangroves. However, the mangrove area have been degraded from 4.2 million in 1980 to only 3.1 million in 2011 (C. Giri, et. al., 2011). Mangroves are among the most carbon-rich forests in the tropics (D.C. Donato, et, al., 2011) and to contributing potentially in reducing greenhouse gas emissions (Bouillon, 2011). Mangrove forests in North Sumatera existed in the east coastal of Sumatera Island and are rapidly threatened due to anthropogenic activities such as conversion for aquaculture, filling and use of mangrove for urban development (Basyuni, Putri, and Murni, 2015).

Mangroves are of particular importance for biogeochemical recycling of carbon and associated elements along the tropical coastal region. Land use and land cover maps are fundamental towards coastal management planning and practice to calculate historical emissions, predicting future emissions as well as mitigation actions for emission reduction scenario by integrating land use-based map and regional action plans (Johana, 2013).

Indonesia has declared its commitment to reduce emissions by $26-41 \%$ in 2020 . More than $50 \%$ of the emission reduction target is intended from the land-use, land use-change and forestry sector (LULUCF). Due to large geographic coverage in Indonesia, potential reduced emissions from land-based sector are implemented in regency, even smaller scale levels through Regional Action Plan for Greenhouse Gas Emissions Reduction (Rencana Aksi Daerah Penurunan Gas Rumah Kaca/RAD GRK)

In order to better understand the perspective of local wisdom of Jaring Halus Village communities on the existence of mangrove forest and rehabilitation and to describe the land-use and landcover changes between 2006 and 2012 of Jaring Halus Village, Langkat, North Sumatra, Indonesia 
and their implications to carbon dioxide emissions was attempted.

\section{MATERIALS AND METHODS}

\section{A. Study Area}

The study was carried out in Jaring Halus village, Langkat regency, North Sumatra province, Indonesia (Fig. 1).

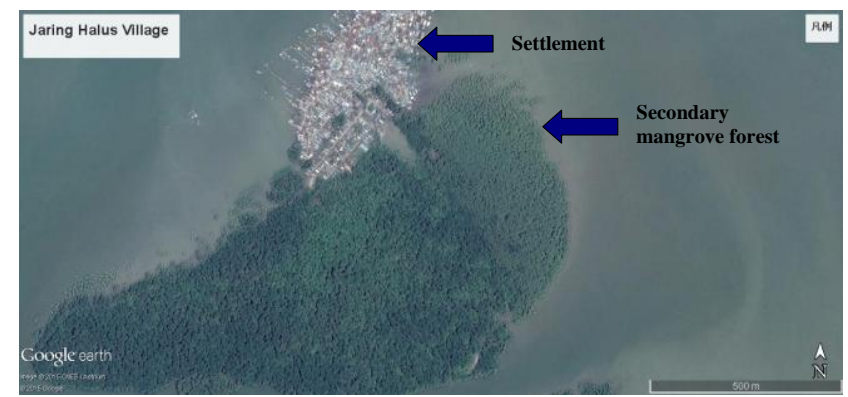

Fig. 1. Map location of study area

This village is situated at between $03^{\circ} 51^{\prime} 30^{\prime \prime}$

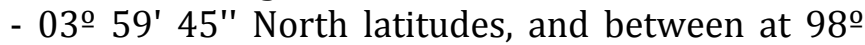
30' - 98을 42 ' East longitudes.

\section{B. Dataset}

Land use and land-cover data between 2006 and 2012 of Jaring Halus village was obtained from Ministry of Forestry, Government of Indonesia and Landsat 7 Enhanced Thematic Mapper Plus (ETM+) satellite image dated on July 24, 2006 and May 27, 2012 were acquired from USGS (http://glovis.usgs.gov/). The Regional Land Use Plan (Rencana Tata Ruang Wilayah/RTRW) map of North Sumatra Province provided the spatial planning zone of this village year 2012 dated on March 30, 2012 was derived from Development Planning Agency (Badan Perencanaan Pembangunan) of North Sumatra Province.

\section{Analysis of Land Use and Land-Cover changes}

Interpretation of the landsat images was conducted by applying supervised classification with maximum likelihood algorithm method as previously reported (Donoghue and Mironnet, 2002). Image pre-processing, process of image interpretation, image classification and change detections were carried out by ERDAS Imagine 8.7 (ERDAS, Atlanta). Ground check was conducted by employing Global Positioning System (GPS) to collect information of recent land use/land-cover.
The information was used as guidance for image geometric correction and image rectification.

\section{Field Observation and Carbon Stock Measurement}

In order to identify land-cover class in this village, field observations was performed. The information from the fields was used in coincidence with satellite imagery categories. GPS data were collected to create GPS coordinates for each class of land use. The combination of various data such as land-cover data, structure and composition of existing species were purposely sampled. Furthermore the estimation of oil palm plantation and agriculture plant ages were made by interviewing with local communities. This information was important during land use/landcover classification of satellite imagery data (Prasetyo, et, al., 2008).

The biomass of each class of land-cover was measured using the species-specific allometric equations with $\mathrm{dbh}$ as the independent variable method (Komiyama, Ong, and Poungparn, 2008). The carbon stock of each land-cover was determined by converting the biomass value into carbon stock by multiplying them by 0.5 (Saatchi, et, al., 2011). The carbon stock of secondary mangrove forest was $284.2 \mathrm{t} / \mathrm{ha}$ and settlement was 52.58 t/ha.

\section{E. Greenhouse gas measurements and developing mitigation scenario}

The REDD Abacus SP software version 1.1.7 (Harja, et. al., 2011) developed by the World Agroforestry Center was used to measure the GHG emissions from land use/land-cover of Jaring Halus village. This carbon dioxide emission requires a dataset on carbon stock levels as emission factor for each land use category (settlement and secondary mangrove forest). Thus, the approach of emission was calculated from carbon stock difference level of land-use.

\section{F. Local wisdom anaylsis}

Perspective of community in Jaring Halus village on the existance mangrove forests, changing mangrove, present state of mangrove and rehabilitation activity were analysed using questionnaires. Seventy head of household from a total of 769 and five key persons including head and vice village, community leaders, head of farmer and fisherman association were collected to answer 
closed-ended questions (Kealy and Turner, 1993). The respondents are given a list of predetermined responses from which to choose their answer, including every possible response and its meaning (Kealy and Turner, 1993)

\section{RESULTS AND DISCUSSION}

The results will be discussed in three subsections; perspective of local community on mangrove and rehabilitation, land-use/land-cover changes between 2006 and 2012, and carbon dioxide emission and developing scenario to reduce carbon dioxide emissions.

\section{A. Perspective of local community on mangrove and rehabilitation}

This study described the perspective of community knowledge on the existance of mangrove, changing mangrove, and mangrove rehabilitation. Table 1 shows perspective of community knowledge on mangrove and mangrove condition. More than $80 \%$ of local community knew mangrove ecosystem as well as the mangrove benefits. Furthermore, more than $71 \%$ of respondents understood the physical function of mangrove and disagreed to converse to other purposes (Table 1). Other the other hand, local community of Jaring Halus was shown to have better mangrove within 5 years (Table 1).

The sustainable mangrove in Jaring Halus village related to their local wisdom to maintain as well as use for daily. According to respondents, there are three unwritten rules to manage this mangrove forests, only dead trees that could be used for firewood, to utilize part of mangrove woods for wedding or death ceremony, it is obligatory to obtain permission from village authority, and to commercially utilize mangroves, there is big punishment, based on the experiences of respondent, no one of community member against this law.

Table 1. Perspective of community knowledge on mangrove and mangrove condition

\begin{tabular}{lc}
\hline Aspect & Relative proportion (\%) \\
\hline Knowing on mangrove forest & 84.3 \\
Understanding the benefit of mangrove & 87.1 \\
Understanding mangrove as coastal protection & 71.4 \\
Mangrove is important for their lives & 71.4 \\
Understanding the changing mangrove within 5 years & 92.9 \\
Disagreement for mangrove conversion & 74.3 \\
A good conditon of current mangrove & 92.9 \\
Awareness of degraded mangrove & 90.0 \\
Better mangrove condition within 5 years & 92.9 \\
\hline Data are expressed as mean from 75 respondent questionnaires
\end{tabular}

Data are expressed as mean from 75 respondent questionnaires
Table 2 depicts the perspective of community knowledge on mangrove rehabilitation, majority needed rehabilitation and involved in this activity. There are $60 \%$ community understood how to plant and maintain rehabilated mangrove (Table 2).

\begin{tabular}{lc} 
Table 2. Perspective of community knowledge on mangrove rehabilitation \\
\hline Aspect & Relative proportion (\%) \\
\hline Understanding how to plant and maintain rehabilated mangrove & 60.0 \\
Necessary and purpose of rehabilitation & 90.0 \\
Community involved in rehabilitation & 90.0 \\
Multi stake holders involved in the rehabilitation efforts & 80.0 \\
\hline Data are expressed as mean from 75 respondent questionnaires
\end{tabular}

Data are expressed as mean from 75 respondent questionnaires

It has been reported that three main criteria for the succesful rehabilitation, these are the effectiveness of planting, the rate of flora and fauna, and efficiency of rehabilitation (Field, 1999). Therefore rehabilitation efforts should in accordance within the frame work of regional development (Basyuni, Putri, and Murni, 2015 ).

\section{B. Land-use/land-cover changes between 2006 and 2012}

The maximum likelihood supervised classification resulted to categorize land use/landcover in Jaring Halus village. The land use/landcover changes in Jaring Halus between 2006-2012 are depicted ion Fig. 2 and Table 3.

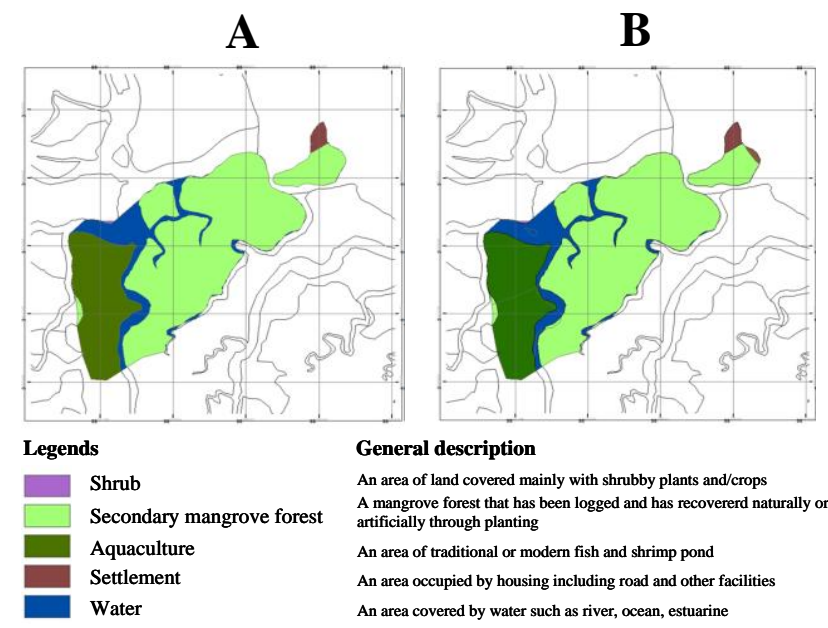

Fig. 2. Land-use and land-cover of Jaring Halus between 2006 (A) and 2012 (B)

Our current study found five land-use changed during 2006-2012, namely shrub, settlement, water, secondary mangrove forest and aquaculture. Secondary mangrove increased slightly by 3.23 ha during 6 years (Table 3, Fig. 2). On the other hand, settlement decreased slightly 3.23 ha (Table 3 ). No 
change has been noted in shrub, aquaculture, and water body between 2006-2012 (Fig. 2, Table 3).

\begin{tabular}{|c|c|c|c|c|c|c|c|}
\hline & \multirow{2}{*}{$\begin{array}{l}\text { Land use/land-cover } \\
\text { classification }\end{array}$} & \multicolumn{6}{|c|}{ Land use 2006 (ha) } \\
\hline & & Shrub & Settlement & Water & $\begin{array}{c}\text { Secondary } \\
\text { mangrove forest }\end{array}$ & Aquaculture & Total \\
\hline \multirow{6}{*}{ 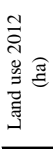 } & Shrub & 1.03 & & 0.00 & & & 1.03 \\
\hline & Settlement & & 12.58 & & & & 12.58 \\
\hline & Water & & & 132.12 & & & 132.12 \\
\hline & Secondary mangrove forest & & 3.23 & 0.00 & 705.46 & & 708.70 \\
\hline & Aquaculture & & & 0.00 & & 237.07 & 237.07 \\
\hline & Total & 1.03 & 15.82 & 132.12 & 705.46 & & 1091.50 \\
\hline
\end{tabular}

Our current results disagreed with previous results that drove some attentions with reference to the conversion of mangrove into intensive land use from 2006 to 2012 in Karang Gading and Langkat Timur Laut Wildlife Reserve (Basyuni, Putri, and Murni, 2015 ). Two differences, firstly, aquaculture and oil palm plantation were found as a main source of mangrove deforestation. Secondly, oil palm plantation grew very rapidly in the same period (Basyuni, Putri, and Murni, 2015 ).

An analysis of agricultural and deforestation statistics for the period 1990-2005 found that more than half of oil palm plantation in Indonesia including in North Sumatra had resulted in deforestation (Koh and Wilcove). Conversion to aquaculture is major cause of mangrove deforestation in Indonesia, but not in this study. Shrimp aquaculture or fish pond has been one of the reasons for mangrove conversion (Primavera, 2006).

\section{A. Carbon dioxide emission and developing scenario to reduce carbon dioxide emissions}

Mangroves are of particular importance for biogeochemical recycling of carbon and associated elements along the tropical coastal region. A historical emission detected during 2006-2012 decreased significantly. This result indicates that the is a GHG sequestrationer (Fig. 3). Future carbon emission shows decreased until year 2030 .

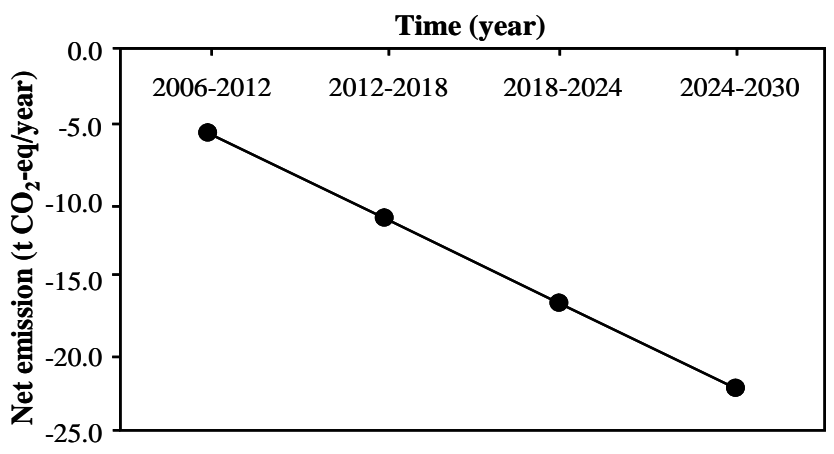

Fig. 3. Net carbon emission in Jaring Halus viillage
However, in order to conserve this secondary mangrove forests, mitigation scenario was carried out to establishing nursery and planted after 3-6 months germinated, rehabilitation of degraded area, and unwritten rules concerning with the utility and cutting of mangrove trees with approval of village authority. Furthermore, the proper actions are also needed to maintain the presence of secondary mangrove forest with a relatively high carbon sequestration potential and promoting rehabilitation programs in the region, especially in shrubs or an abandoned aquaculture.

\section{CONCLUSION}

Carbon sequestration occurred in the mangrove forest of Jaring Halus village, suggested that local wisdom contributed to maintaining the existence of mangrove forest in the village. In order to maintain the existing mangrove forest, mitigation actions were performed to increase carbon sequestration.

\section{ACKNOWLEDGMENTS}

This study was partly supported by a IbM (Ipteks bagi Masyarakat) Grant and a Competence Grant from the Directorate for Research and Community Service, Ministry of Research, Technology and Higher Education, Republic of Indonesia.

\section{REFERENCES}

A. Komiyama, J.E. Ong, and S. Poungparn, "Allometry, biomass, and productivity of mangrove forests: A review," Aquat. Bot., vol 89, pp. 128-137, 2008.

C.D. Field, "Rehabilitation of mangrove ecosystems: an overview," Marine Poll. Bull., vol 37, pp. 812, 1999.

C. Giri, E. Ochieng, L.L. Tieszen, Z. Zhu, A. Singh, T. Loveland, J. Masek, and N. Duke, "Status and distribution of mangrove forests of the world using earth observation satellite data," Global Ecol. Biogeogr., vol. 20, pp. 154-159, 2011.

D.C. Donato, J.B. Kauffman, D. Murdiyarso, S. Kurnianto, M. Stidham, and M. Kanninen, "Mangroves among the most carbon-rich 
forests in the tropics," Nature Geosci., vol. 4, pp. 293-297, 2011. D.N.M. Donoghue, and N. Mironnet, "Development of an integrated geopgraphical information system prototype for coastal habitat monitoring," Comput. Geosci. vol. 28, pp. 129-141, 2002.

D. Harja, S. Dewi, M. van Nordwijk, A. Ekadinata, and A. Rahmanulloh A. 2011. "REDD Abacus SP User Manual and Software," World Agroforestry Center - ICRAF, SEA Regional Office, Bogor, Indonesia, 2011.

F. Johana, S. Suyanto, A. Widayati, M.T. Zulkarnain, D. Muller, and A. Budiman, "Local mitigation actions supporting the low emission development plan in Kutai Barat District, Indonesia - initial process,". Brief No. 35. World Agroforestry Centre - ICRAF, Southeast Asia Regional Program, Bogor, Indonesia, pp. 1-6, 2013.

L.B. Prasetyo, S.A. Wibowo, H. Kartodihardjo, F. Tonny, Haryanto, R. Sonaji, and Y. Setiawan, "Land use and land-cover changes of conservation area during transition to regional autonomy: case study of Balairaja Wildlife Reserve in Riau Province, Indonesia," Tropics, vol. 17, pp. 99-108, 2008.

L.P. Koh, D.S. Wilcove, "Is oil palm agriculture really destroying tropical biodiversity?" Conservation Letters 1:60-64.
M. Basyuni, L.A.P. Putri, and M.B. Murni, "Implication of land-use and land-cover change into carbon dioxide emissions in Karang Gading and Langkat Timur Luat Wildlife Reserve, North Sumatra, Indonesia," J. Manaj. Hut. Trop. vol. 21, pp. 25-35, April 2015.

M.J. Kealy, and R.W. Turner, A test of the equality of closed-ended and open-ended contingent valuations, Am. J. Agr. Econ., vol 75 (2), pp. 321-331, 1993.

Primavera JH 2006. Overcoming the impacts of a aquaculture on the coastal zone. Ocean \& Coastal Management 49:531-545.

S. Bouillon, "Carbon cycle: Storage beneath mangroves," Nature Geosci. vol. 4, pp. 282283, 2011.

S.S. Saatchi, N.L. Harris, S. Brown, M. Lefsky, E.T.A. Mitchard, W. Salas, B.R. Zutta, W. Buermann, S.L. Lewis, S. Hagen, S. Petrova, L. White, M. Silman, and A. Morel, "Benchmark map of forest carbon stocks in tropical regions across three continents," Proc. Natl. Acad. Sci. U.S.A., vol.108, pp. 9899-9904, 2011. 